\title{
Parents' perception of the sleep habits and quality of preschool-aged children
}

Perceção parental sobre hábitos e qualidade do sono das crianças em idade pré-escolar Percepción parental sobre los hábitos y la calidad del sueño de los niños en edad preescolar Ernestina Maria Batoca Silva*; Paula Alexandra Duarte Simôes**; Mónica Cristina dos Santos Amaral de Macedo***; João Carvalho Duarte****; Daniel Marques Silva*****

\begin{abstract}
Background: Sleep quality is essential for children's well-being during the day and to optimize their school performance.

Objectives: To characterize the sleep habits and quality of preschool-aged children based on their parents' perceptions.

Methodology: A quantitative, descriptive, and correlational study was conducted using a nonprobability sample of 642 parents of children attending preschool in the municipalities of Albergaria-a-Velha (64.2\%) and Agueda (35.8\%). The Pittsburgh Sleep Quality Index was used.

Results: The results showed that $64.8 \%$ of children had a good sleep quality; $47.2 \%$ of them took 16 to 30 minutes to fall asleep; $88.3 \%$ of them slept between 9 and a half hours and 10 and a half hours; $84 \%$ had very good habitual sleep efficiency; $75.4 \%$ had sleep disturbance; $97.5 \%$ did not use sleeping pills; and $76.6 \%$ had no daytime dysfunction.

Conclusion: Although sleep quality is good in most of the children, a number of concerns were identified. Thus, sleep hygiene education should be provided to parents and the preschool community.
\end{abstract}

Keywords: sleep hygiene; child, preschool; nurses

\section{Resumo}

Enquadramento: A qualidade do sono é determinante para o bem-estar durante o dia e para otimizar o desempenho nas atividades de cada criança.

Objetivos: Caracterizar os hábitos e a qualidade de sono percebidos pelos pais das crianças em idade pré-escolar. Metodologia: Estudo quantitativo, descritivo e correlacional. Amostra não probabilística com 642 pais de crianças que frequentavam o ensino pré-escolar dos concelhos de Albergaria-a-Velha (64,2\%) e Águeda (35,8\%). Utilizou-se o Índice de Qualidade de Sono de Pittsburgh. Resultados: Apurou-se que $64,8 \%$ das crianças foi classificada como tendo boa qualidade de sono; $47,2 \%$ demoram a adormecer entre 16 a 30 minutos; 88,3\% dormem entre $09 \mathrm{~h} 30$ e $10 \mathrm{~h} 30$ horas; $84 \%$ apresentam uma eficiência habitual do sono muito boa; $75,4 \%$ referem perturbação do sono; $97,5 \%$ não usam medicação para dormir e 76,6\% não referem disfunçáo diurna.

Conclusáo: Embora a qualidade do sono seja boa na maioria das crianças, foram identificados vários aspetos preocupantes. Assim, é necessário que seja fornecida educação sobre a higiene do sono aos pais e à comunidade pré-escolar.

Palavras-chave: higiene do sono; pré-escolar; enfermeiras e enfermeiros

*Ph.D., Coordinating Professor, Polytechnic Institute of Viseu, 3500-843, Viseu, Portugal [ernestinabatoca@sapo.pt]. Contribution to the article: literature search; substantial contribution to data analysis and discussion; article writing. Address for correspondence: Rua da Peça, $\mathrm{n}^{\circ}$ 64, Esculca, 3500-423, Viseu, Portugal.

$n^{\circ} 64$, Esculca, 3500-423, Viseu, Portugal.
${ }_{*}^{*}$ MSc., RN, ACeS Baixo Vouga, 3804-502, Aveiro, Portugal [padsimoes27@gmail.com]. Contribution to the article: literature search; data collection; statistical treatment and evaluation; data analysis and discussion

***:MSc., RN, ACeS Baixo Vouga, 3804-502, Aveiro, Portugal [toomonica@gmail.com]. Contribution to the article: literature search; data collection; statistical treatment and evaluation; data analysis and discussion.

****Ph.D., Coordinating Professor, School of Health of Viseu, 3500-843, Viseu, Portugal [duarte.johnnv@gmail.com].Contribution to the article: statistical treatment and evaluation. ******Ph.D., Coordinating Professor, School of Health of Viseu, 3500-843, Viseu, Portugal [dsilva.essv@gmail.com].Contribution to the article: data analysis and discussion; article writing.

\section{Resumen}

Marco contextual: La calidad del sueño es determinante para el bienestar durante el día y para optimizar el desempeño en las actividades que realiza el niño.

Objetivos: Caracterizar los hábitos y la calidad del sueño percibidos por los padres de los niños en edad preescolar. Metodología: Estudio cuantitativo, descriptivo y correlacional. Muestra no probabilística con 642 padres. Los niños asisten a la enseńanza preescolar de los municipios de Albergaria-a-Velha $(64,2 \%)$ y Águeda (35,8\%). Se utilizó el Índice de Calidad del Sueño de Pittsburgh.

Resultados: Se constató que al $64,8 \%$ de los niños se le clasificó como con buena calidad del sueño; el 47,2\% tarda en dormirse entre 16 y 30 minutos; el 88,3\% se duerme entre las $9 \mathrm{~h} 30$ y las $10 \mathrm{~h} 30$; el $84 \%$ presenta una eficiencia habitual del sueño muy buena; el 75,4\% indicó trastornos del sueńo; el 97,5\% no usa medicamentos para dormir y el 76,6\% no indicó ninguna disfunción diurna. Conclusión: En la mayoría de los niños la calidad del sueño es buena, pero hay aspectos preocupantes, por lo que es necesario educar sobre la higiene del sueño a los padres y a la comunidad educativa preescolar.

Palabras clave: higiene del sueño; preescolar; enfermeros 


\section{Introduction}

Sleep is a physiological need with biological functions, including body restoration and energy conservation which are important for physical and emotional balance (Pimentel \& Rente, as cited in Seixas, 2009). Throughout the lifecycle, sleep serves so many vital purposes that sleep deprivation can lead to death. These functions are essential for the maintenance of alertness, energy conservation, promotion of anabolic processes, the functioning of central thermoregulatory mechanisms, the production of certain cytokines that increase the activity of the immune system, the development, maturation, and plasticity of the brain, the formation and consolidation of memory, the regulation of various metabolic processes, and as a substrate of dreams (Paiva \& Penzel, as cited in Silva, 2012).

In addition, Boscolo, Sacco, Antunes, Mello, and Tufik (as cited in Seixas, 2009) argue that healthy people enjoy the benefits of sleep, namely in their physical, psychological, emotional, intellectual, and social health, with an impact on their professional satisfaction and better performance at work, school, and leisure activities.

Childhood is characterized by a large number of changes in neuromotor development. Thus, physical rest and energy recovery are of utmost importance for children due to their impact on infant growth and development. Human growth is a complex process influenced by several hormones which will modulate diverse biological occurrences (brain, blood, organs, muscles, and bones). The human growth hormone is one of the key hormones in this process because, although it is produced throughout the day, it is also produced at night during deep sleep (Cordeiro, 2015).

Insufficient or poor quality of sleep in children can lead to several disorders, such as coordination and concentration problems during the day, and, consequently, to decreased school performance, increased risk of accidents, moodiness, fatigue, and irritability (Monteiro, 2014). On the other hand, cognitive performance benefits from an appropriate amount of good quality sleep, with effects on health throughout life (Kelly, Kelly, \& Sacker, 2013).
Therefore, considering that the prevalence of worrying sleep habits in preschool-aged children ranges from 10 to $30 \%$ (Owens \& Mindell, 2011; Teng, Bartle, Sadeh, \& Mindell, 2012) and that the impact and stress of pediatric sleeping problems extend beyond the child to the parents and the rest of the family (Caldwell \& Redeker, 2015), this study was conducted with the purpose of characterizing the sleep habits and quality of preschool-aged children based on their parents' perceptions. It aims to raise awareness of the promotion of sleep hygiene and the creation of good sleep habits among preschool-aged children.

\section{Background}

Sleep plays a major role in human well-being and, throughout the different stages of the lifecycle, its importance is reflected in different forms and has different consequences. Sleep changes over the years, with a progressive reduction in its duration. Newborns spend more time sleeping than a school-aged child or an adolescent. Even during adulthood, both the duration and the type of sleep change with age. "However, it is during childhood that these changes occur more quickly, both in terms of sleep duration and in the organization of the various stages of sleep" (Silva, 2012, p. 23). Between the ages of 3 and 6 , children sleep on average 10 to 12 hours per day, with or without a nap, which can change from child to child (Cordeiro, 2015). In this age group, the main change is the end of the daytime nap. However, according to Guimarães (2013), 25\% of 5-year-olds continue to take naps. The nap is a biological need from birth, lasting about 4 hours and progressively decreasing as the child grows (Monteiro, 2014). In infants, morning naps, in which the rapid-eye-movement (REM) sleep prevails, are associated with brain growth and maturation, while afternoon naps, with a prevalence of non-REM sleep, promote physical and psychological recovery. Napping is not a waste of time and will not influence the night sleep, because the less children sleep, the more hyperactive they become, making it more difficult to fall asleep at night (Monteiro, 2014). According to Silva (2012, p. 25), "determin- 
ing the number of hours of sleep of a child is not always easy and determining the quality of sleep is even more difficult." It is known that changes in the amount and quality of sleep have physical, psychological, and cognitive consequences (Cordeiro, 2015). Children's sleep habits are associated with biological, maturational, and temperamental factors, which differ according to their culture, and are, in turn, influenced by parents' behaviors and routines (Grandner, 2012; Seixas, 2009). According to the transactional model proposed by Sadeh, Tikotzky, and Scher (2010), the relationships between parental behaviors and infant sleep are bidirectional, that is, if it is a fact that the child's age and characteristics influence the sleeping patterns, the best predictors are associated with the parents' behavior at the beginning and maintenance of their children's sleep. Among other aspects, this relationship is not always balanced and it may lead to poor sleep habits and changes in sleep quality. On the other hand, "children with sleep problems disrupt the family's stability, so the problem must be addressed together, and breaking this cycle will undoubtedly benefit the whole family." (Seixas, 2009, p. 47). Honaker and Meltzer (2016) argue that sleep is still an under-addressed topic in primary care, which is an excellent area for increasing parents' knowledge and awareness. Physicians and nurses play an important role in supporting and educating parents and assisting in the prevention, identification, and management of children's sleeping problems. Intervention programs involve the establishment of good sleep habits and routines for children by suggesting some simple measures, such as creating the appropriate room environment (a room that is dark, clean, quiet, airy and a comfortable temperature); having a bed that is appropriate to the child's age with little bedding; establishing a regular sleep-wake schedule so that children can create their own rhythm (Chambel, 2013; Cordeiro, 2015). In this case, parents must establish a sleep routine and avoid breaking the rules, such as taking a bath, having dinner, brushing teeth, going to the bathroom or reading a bedtime story (Monteiro, 2014). To maintain a suitable environment, watching television in the bedroom is completely inappropriate, as well as playing computer games or using other audiovisual media because it will hyperstimulate children and young people's brain and, consequently, influence their sleep (Monteiro, 2014). Lélis, Cipriano, Cardoso, Lima, and Araújo (2014) concluded that the habit of watching television, playing computer or video games, among others, had a higher impact on sleepiness among boys than among girls. More than one hour in front of a screen influences the occurrence of sleepiness as a sleep disorder among boys. Another important measure, which has already been used as a non-pharmacological intervention measure to improve the sleep pattern and found capable of increasing children's self-esteem, social acceptance, and sense of well-being (Monteiro, 2014), is to encourage children and young people to engage in physical activity, preferably outdoor, and to spend time with their peers face-to-face (Cordeiro, 2015). Other healthy behaviors to promote sleep including reducing stimulant factors such as foods and drinks containing caffeine (soft drinks, coffee, and tea) and relaxing more (Semedo, 2016).

\section{Research questions}

What are the sleep habits and quality of preschool-aged children based on their parents' perceptions?

Are some of the child's habits associated with sleep quality? To what extent?

\section{Methodology}

A quantitative, descriptive, and correlational study was conducted using a nonprobability and convenience sample of parents of children attending preschool. Two inclusion criteria were applied in the recruitment process: child enrolled for the 2015/2016 academic year in preschool education in the municipalities of Albergaria-a-Velha and Águeda, and living with at least one of the parents.

Data were collected using the Portuguese version of the Pittsburgh Sleep Quality Index (PSQI-VP; Bertolazi et al., 2011) and an ad-hoc questionnaire about the children's sociodemographic characteristics and anthro- 
pometric data. Ethical procedures were met, namely the request to the Ethics Committee of the Health School of Viseu (Opinion No. 15/2015) and the National Commission for Data Protection, with a favorable opinion issued. Authorization was requested from the directors of the schools' clusters in the municipalities of Águeda and Albergaria-a-Velha. The researcher went to each institution to deliver the data collection instruments in an envelope to the teacher in charge, who then delivered them to the children's parents. Each envelope also contained the informed consent form to be signed by the parents. After completed, each questionnaire was placed inside a sealed, unidentified envelope, to ensure the children's anonymity, and returned to the teacher in charge, who then handed it over to the researcher. Data were collected between January and April 2016.

The PSQI is a 19-item retrospective scale which refers to the prior month only. The questions are grouped into seven different dimensions (subscales), each weighted equally from $0-3$ : Subjective sleep quality; Sleep latency; Sleep duration; Habitual sleep efficiency; Sleep disturbances; Use of sleeping medication; and Daytime dysfunction. The sleep quality index results from the sum of the seven dimensions, ranging from 0 to 21 , considering that the higher the score, the lower the quality of sleep. According to their scores, children were classified as having a good sleep quality (score $\leq$ 5 ) and a poor sleep quality (score $>5$ ). In this study, the analysis of the internal consistency revealed reasonable Cronbach's alpha values for the total scale (0.698) and for each item, which ranged from 0.663 (Subjective sleep quality) to 0.686 (Use of sleeping medication). The chi-square test $\left(\mathrm{x}^{2}\right)$ was used for data analysis. Statistical analysis was performed using IBM SPSS Statistics software, version 23, and Analysis of Moment Structures (AMOS), version 23 (2012) for Windows. The level of significance was set at 5\% $(p=0.05)$.

\section{Results}

\section{Sociodemographic characterization}

The sample consisted of 642 parents (97.2\% of mothers and $2.8 \%$ of fathers), with a min- imum age of 20 years and maximum age of 62 years (mean age of $37.47 \pm 5.94$ years). With regard to education, $74.3 \%$ of mothers had completed secondary education and $44.2 \%$ of fathers had completed the third cycle of basic education ( $9^{\text {th }}$ grade).

Children were aged between 3 and 6 years (with a mean age of $4.55 \pm 0.93$ years); $51.7 \%$ of them are girls; most of them (58.1\%) are the couple's first child; $71.23 \%$ of children live in nuclear families; $64.2 \%$ of children attended pre-school in Albergaria-a-Velha and 35.8\% in Águeda. The majority (51.2\%) of them attended a public institution, $45.7 \%$ attended a private social solidarity institution, and 3.1\% attended a private institution.

\section{Lifestyles and sleep habits}

With regard to the consumption of stimulant drinks, $44.3 \%$ of children drank drinks containing theine (coffee, tea or soft drinks) regularly, of whom $18.4 \%$ did not sleep well. In this sample, $58.6 \%$ of children reported eating sweets and chocolates often, of whom $20.9 \%$ did not sleep well. In the statistical analysis, the $X^{2}$ test found no statistical significance between sleep quality and the consumption of drinks containing theine $\left(X^{2}=5.773 ; p=0.056\right)$ or the consumption of sweets $\left(X^{2}=0.010 p=0.495\right)$. As regards physical activity, most children (57.7\%) had sedentary habits and $42.3 \%$ of children engaged in physical activity, which influences sleep quality $\left(X^{2}=12.995 ; p=0.002\right)$. In this sample, $63.7 \%$ of children went to bed between 9 and 10 p.m. on weekdays and $72.6 \%$ went to bed $\geq$ 10 p.m. at the weekend. On weekdays, $56.3 \%$ of children wake up before 8 a.m. and $89.9 \%$ of them wake up after $8 \mathrm{a} . \mathrm{m}$. at the weekend. The total duration of sleep per day is between 10 and 13 hours for most children (74.1\%), thus suggesting an association with sleep quality $\left(X^{2}=\right.$ 16.569 and $p=0.000$ ). Daily screen time (tablets or smartphones) during the week was less than 60 minutes for $83.8 \%$ of children, which increased to $60-120$ minutes at the weekend (54.8\%). However, no statistical significance was found with sleep quality, both during the week $\left(X^{2}=1.388 ; p=0.500\right)$ and at the weekend $\left(X^{2}=0.221\right.$ and $\left.p=0.895\right)$.

With regard to sleeping alone or not, $64.8 \%$ of children slept alone, of whom $41 \%$ had a good sleep quality. The transition from their parents' 
room to their own room was easy for $47.6 \%$ of children, initially difficult for $22.3 \%$ of children, and always difficult for $30.1 \%$ of children. A statistical significance was found between the habit of sleeping alone or not $\left(X^{2}=5.207\right.$ and $p=$ $0.014)$ and the transition to their own room and sleep quality $\left(X^{2}=8.172\right.$ and $\left.p=0.013\right)$.

\section{Sleep quality}

The minimum and maximum scores ranged from 0 to 3 in all dimensions of the scale
(Table 1). The total index has a minimum score of 0 and a maximum score of 14 . The mean variability was low, ranging from the lowest in Subjective sleep quality $(M=0.60)$ to the highest in Habitual sleep efficiency $(M$ =4.16). For the total index, the mean value was 4.16. The values of skewness and kurtosis for the total scale revealed leptokurtic curves with left bias. The coefficients of variation revealed moderate to high dispersions in the total scale and its dimensions.

Table 1

Statistics of parents' perceptions of their children's sleep quality

\begin{tabular}{lccccccc}
\hline Sleep Quality & Min & Max & $\boldsymbol{M}$ & $\boldsymbol{S D}$ & $\mathbf{C V ~ ( \% )}$ & Sk/error & K/error \\
\hline Subjective sleep quality & 0 & 3 & 0.60 & 0.66 & 55 & 1.04 & 0.96 \\
Sleep latency & 0 & 3 & 0.85 & 0.71 & 83.6 & 0.38 & 0.19 \\
Sleep duration & 0 & 3 & 1.11 & 0.32 & 29.18 & 2.20 & 0.97 \\
Sleep disturbance & 0 & 3 & 1 & 0.51 & 27 & 0.27 & 0.97 \\
Use of sleeping medication & 0 & 3 & 0.93 & 0.422 & 45.4 & 5.18 & 0.96 \\
Daytime dysfunction & 0 & 3 & 0.78 & 0.54 & 69.4 & 1.96 & 0.10 \\
Habitual sleep efficiency & 0 & 3 & 4.16 & 1.97 & 47.35 & 2.7 & 0.10 \\
Sleep quality (global) & 0 & 14 & 4.16 & 1.97 & 47.30 & 12.28 & 13.30 \\
\hline
\end{tabular}

Note. Min = Minimum; Max = Maximum; $M=$ Mean; $S D=$ Standard deviation; $C V=$ Coefficient of Variation; $\mathrm{Sk} /$ error $=$ Skewness/error; K/error $=$ Kurtosis/error.

Sleep quality was classified based on the cutoff points recommended by the scale's author. The results showed that $64.8 \%$ of the participants had a good sleep quality and about one-third of the children (35.2\%) had a poor sleep quality. A good sleep quality was more predominant among girls (33.8\%) and children aged 3-4 years (27.3\%). No statistically significant differences were observed for gender $\left(X^{2}=0.096 ; p=0.410\right)$ or age $\left(X^{2}=\right.$ 1.994; $p=0.095)$.

With regard to the dimensions of the scale (Table 2), the results showed that most of the parents perceived their children's subjective sleep quality as very good $(47.8 \%)$ or fairly good $(46.3 \%)$. No statistically significant differences were found for gender $\left(X^{2}=2.038 ; p\right.$ $=0.550)$ or age $\left(X^{2}=5.266 ; p=0.153\right)$.

In the Sleep latency dimension, $47.2 \%$ of children scored between 1 and 2 points, that is, they took 16 to 30 minutes to fall asleep. No statistically significant differences were found for gender $\left(X^{2}=0.672 ; p=0.880\right)$ or age group $\left(X^{2}=0.225 ; p=0.973\right)$.

In the Sleep duration dimension, it should be noted that most children $(88.3 \%)$ slept between 9 and a half and 10 and a half hours per day, of whom $44.9 \%$ were girls and $49.8 \%$ were aged 5-6 years. No statistically significant difference was found for gender $\left(X^{2}=1.706 ; p\right.$ $=0.426)$ or age group $\left(X^{2}=2.783 ; p=0.249\right)$. The Habitual sleep efficiency dimension refers to the ratio between the number of hours slept and the number of hours in bed. In this sample, $84 \%$ of children had a $\geq 85 \%$ efficiency (very good), with most of them being girls $(42.4 \%)$ and children aged 5-6 years $(47.5 \%)$. No statistically significant difference was found for gender $\left(X^{2}=5.630 ; p=0.129\right.$; Monte Carlo simulation). A statistical significance was found for age group $\left(X^{2}=8.630 ; p=0.030\right)$ among children aged 3-4 years and a $<65 \%$ Habitual sleep efficiency. The contingency coefficient $(C C)$ showed a weak $(C C=0.115)$ 
but significant $(p=0.030)$ association.

In this sample, Sleep disturbance was evident at least once a week in $75.4 \%$ of children, being higher in girls $(38.5 \%)$ and children aged $5-6$ years $(42.8 \%)$. No significant differences were found for gender $\left(X^{2}=2.267 ; p=0.519\right)$ or age group $\left(X^{2}=3.024 ; p=0.388\right)$.

In the Use of sleeping medication dimension, $97.5 \%$ of children did not use any sleeping medication. Based on the $X^{2}$ tests, no statis- tically significant differences were found for gender $\left(X^{2}=0.417 ; p=0.347\right)$ or age $\left(X^{2}=\right.$ $2.258 ; p=0.106)$.

In the Daytime dysfunction dimension, it should be noted that $76.6 \%$ of children did not show any signs of sleepiness during the past month while playing, eating or performing other activities. No statistically significant differences were found for gender $\left(X^{2}=2.013\right.$; $p=0.570)$ or age $\left(X^{2}=5.709 ; p=0.127\right)$.

Table 2

Parents' perceptions of their children's sleep quality

\begin{tabular}{|c|c|c|c|c|c|c|c|c|c|c|}
\hline Dimensions & $N$ & $\%$ & $N$ & $\%$ & $N$ & $\%$ & $N$ & $\%$ & $N$ & $\%$ \\
\hline \multirow{2}{*}{$\begin{array}{l}\text { Subjective sleep } \\
\text { quality }\end{array}$} & \multicolumn{2}{|c|}{ Very good } & \multicolumn{2}{|c|}{ Fairly good } & \multicolumn{2}{|c|}{ Fairly bad } & \multicolumn{2}{|c|}{ Very bad } & \multicolumn{2}{|c|}{ Total } \\
\hline & 307 & 47.8 & 297 & 46.3 & 26 & 4.00 & 12 & 1.9 & 642 & 100.0 \\
\hline \multirow{2}{*}{ Sleep latency } & \multicolumn{2}{|c|}{$0-15 \mathrm{~m}$} & \multicolumn{2}{|c|}{$16-30 \mathrm{~m}$} & \multicolumn{2}{|c|}{$31-60 \mathrm{~m}$} & \multicolumn{2}{|c|}{$>60 \mathrm{~m}$} & \multicolumn{2}{|c|}{ Total } \\
\hline & 220 & 34.3 & 303 & 47.2 & 113 & 17.6 & 6 & 0.9 & 642 & 100.0 \\
\hline \multirow{2}{*}{ Sleep duration } & \multicolumn{2}{|c|}{$<9$ h30 } & \multicolumn{2}{|c|}{$9 \mathrm{~h} 30-10 \mathrm{~h} 30$} & \multicolumn{2}{|c|}{$\geq 10 \mathrm{~h} 30$} & & & \multicolumn{2}{|c|}{ Total } \\
\hline & 2 & 0.4 & 567 & 88.3 & 73 & 11.3 & & & 642 & 100.0 \\
\hline \multirow{2}{*}{$\begin{array}{l}\text { Habitual sleep } \\
\text { efficiency }\end{array}$} & \multicolumn{2}{|c|}{$\geq 85 \%$} & \multicolumn{2}{|c|}{$75-84 \%$} & \multicolumn{2}{|c|}{$65-74 \%$} & \multicolumn{2}{|c|}{$<65 \%$} & \multicolumn{2}{|c|}{ Total } \\
\hline & 539 & 84.0 & 64 & 10.0 & 31 & 4.8 & 8 & 1.2 & 642 & 100.0 \\
\hline \multirow[t]{2}{*}{ Sleep disturbance } & \multicolumn{2}{|c|}{$\begin{array}{l}\text { Not during the } \\
\text { past month }\end{array}$} & \multicolumn{2}{|c|}{$\begin{array}{c}\text { At least once a } \\
\text { week }\end{array}$} & \multicolumn{2}{|c|}{$\begin{array}{c}\text { Once or twice a } \\
\text { week }\end{array}$} & \multicolumn{2}{|c|}{$\begin{array}{l}\text { Three or more } \\
\text { times a week }\end{array}$} & \multicolumn{2}{|c|}{ Total } \\
\hline & 82 & 12.8 & 484 & 75.4 & 72 & 11.2 & 4 & 0.6 & 642 & 100.0 \\
\hline \multirow{2}{*}{$\begin{array}{l}\text { Use of sleeping } \\
\text { medication }\end{array}$} & \multicolumn{2}{|c|}{ Uses medication } & \multicolumn{2}{|c|}{$\begin{array}{l}\text { Does not use } \\
\text { medication }\end{array}$} & & & & & \multicolumn{2}{|c|}{ Total } \\
\hline & 16 & 2.5 & 626 & 97.5 & & & & & 642 & 100.0 \\
\hline \multirow{2}{*}{$\begin{array}{l}\text { Daytime } \\
\text { dysfunction }\end{array}$} & \multicolumn{2}{|c|}{$\begin{array}{l}\text { Not during the } \\
\text { past month }\end{array}$} & \multicolumn{2}{|c|}{$\begin{array}{c}\text { Less than once } \\
\text { a week }\end{array}$} & Once & $\begin{array}{l}\text { twice a } \\
k\end{array}$ & $\begin{array}{l}\text { Thr } \\
\text { tim }\end{array}$ & $\begin{array}{l}\text { more } \\
\text { week }\end{array}$ & & \\
\hline & 492 & 76.6 & 124 & 19.3 & 24 & 3.7 & 2 & 0.4 & 642 & 100.0 \\
\hline
\end{tabular}

Note. $\mathrm{m}=$ minutes; $\mathrm{h}=$ hours.

\section{Discussion}

The purpose of this study was to characterize the sleep habits and quality of preschool-aged children based on their parents' perceptions using the PSQI - VP (Bertolazi et al., 2011). The overall mean score was 4.16, ranging from 0 to 14 . The majority of children were classified as having a good sleep quality. Duarte (2008) found similar results in a study on the sleep quality of adolescents, with $63.4 \%$ showing a good sleep quality and $36.6 \%$ a poor sleep quality. Other studies with pre- school children report that 10 to $30 \%$ of children have problematic sleeping habits (Owens \& Mindell, 2011; Teng et al., 2012).

Girls had a better sleep quality, although boys' scores were very similar. Talhada (2012) showed different results, with girls showing a greater tendency to have sleeping problems than boys.

As regards lifestyles, children who did not engage in any physical activity $(57.7 \%)$ had a poor sleep quality, with statistically significant differences $(p=0.002)$. These data demonstrate that physical activity is import- 
ant to improve the sleeping patterns and that it can be used as a non-pharmacological intervention (Cordeiro, 2015). Daily screen time is not worrying (less than 60 minutes in $83.8 \%$ of children on weekdays, increasing to $60-120$ minutes in $54.8 \%$ of children at the weekend) however, this is a matter that should be discussed with parents. Fable (as cited in Guimarães, 2013) proved that smartphone or tablet screen time is worse than television time in terms of lack of sleep. Children who have access to tablets or smartphones sleep 21 minutes less per night than those who do not use this technology and are more likely to report lack of sleep. According to the same study, having a television in the bedroom is associated with lack of rest or insufficient sleep. Children with a television in their bedroom sleep 18 minutes less than those who do not have these devices in their sleeping environment.

Lélis et al. (2014) found that the family environment influences children's sleep quality because the family's patterns/routines, socioeconomic conditions, and others influence the children's habits.

With regard to sleep duration, most children sleep between 10 and 13 hours a day, which fits into Cordeiro's recommendation (2015) that children should sleep between 10 and 12 hours a day. In a study conducted with children aged 2 to 10 years, Rangel, Batista, Pitta, Anjo, and Leite (2015) found that the median sleep duration per day was 10 hours and that the median time to go to bed was 9.30 p.m. during the week and 10 p.m. at the weekend. These results are in line with those obtained in this study: bedtime between 9 and 10 p.m. for $63.7 \%$ of children during the week and $\geq 10$ p.m. for $72.6 \%$ of children at the weekend.

In addition, as regards lifestyles, this study also analyzed if children slept alone in their bedroom and how this transition happened. Most parents reported that their children slept alone and that the transition to their own room was easy for $47.6 \%$ of children. In both situations, children had a good sleep quality. In the study by Rangel et al. (2015), $15.1 \%$ of children required the presence of a relative to be able to sleep. The research conducted by Lélis et al. (2014) revealed that children from large families, when living in small houses and sleeping in the same room as their parents, show sleep-wake transition disorders. The authors also indicate that family conflicts have an impact on childhood, resulting in more insomnia symptoms when the young person involved turns 18. Children's exposure to a recent life event, such as the loss of a special object or the separation from a loved person, moving to another school, the parents' divorce, or witnessing a family violence situation can trigger sleeping disorders. In this study, a large sample was used to obtain reliable results. However, a methodological limitation may have been the use of a nonprobability sampling technique and the fact that it was a self-administered questionnaire, which was applied only once to measure the sleep parameters. The answers depended on the parents' honesty and sincerity and they could describe more desirable behaviors than reality itself. Another limitation of this study is the comparison with the results obtained in other research studies because the studies on the sleep quality of preschool children are scarce.

Nevertheless, this is an important study because parents were given the opportunity to report on their children's sleep habits and quality.

\section{Conclusion}

This study found that children's sleep quality is mostly good. However, considering that about one-third of the children have poor sleep quality, the need emerges to promote children's sleep among their parents and the preschool community. Thus, the interaction with the families should be promoted during child health consultations, empowering parents to establish bedtime and morning routines and maintain consistency in daytime activities (e.g., leisure activities, homework, and meals). Based on these results, awareness should be raised about the influence of drinks containing theine and the regular consumption of sweets and chocolates.

Action in this area should be broader. Thus, the authors suggest the implementation of an intervention program including kindergartens, children, and families aimed to encour- 
age parents and the education community to promote children's sleep hygiene.

A longitudinal study should also be developed during child health consultations to more accurately assess the aspects involving the family context and the child's lifestyles and sleep habits. Awareness should also be raised about the need to improve policies and strategies for intervention and promotion of healthy life behaviors, which are still unexplored in the 2013 National Plan for Children and Young People's Health, related to sleep habits and their impact on health.

\section{References}

Bertolazi, A., Fagondes, S., Hoff, L. Dartora, E., Miozzo, I., de Barba, M., \& Barreto, S. (2011). Validation of the Brazilian Portuguese version of the Pittsburgh Sleep Quality Index. Sleep Medicine, 12(1), 70-75. doi: 10.1016/j.sleep.2010.04.020

Caldwell, B., \& Redeker, N. (2015). Maternal stress and psychological status and sleep in minority preschool children. Public Health Nursing, 32(2), 101-111. doi: 10.1111/phn. 12104

Chambel, I. D. (2013). Crenças parentais sobre o sono das crianças em idade pré-escolar (Master's dissertation). Retrieved from http://repositorio.ul.pt/handle/10451/10538

Cordeiro, M. (2015). Dormir tranquilo. Lisboa, Portugal: A Esfera dos Livros.

Duarte, J. (2008). Privação do sono, rendimento escolar, equilíbrio psico-afetivo na adolescência (Doctoral thesis). Retrieved from https://repositorio-aberto.up.pt/ handle/10216/19371

Grandner, M. (2012). Sleep duration across the lifespan: Implications for health. Sleep Medicine Review, 16(3), 199-201. doi: 10.1016/j.smrv.2012.02.001

Guimarães, A. C. (2013). Identificação de hábitos de sono, compreensáo do sono e rotinas de sono em crianças de idade escolar: Estudo com crianças e pais (Master's dissertation). Retrieved from http://repositorio.ul.pt/ handle/10451/10415

Honaker, S., \& Meltzer, L. (2016). Sleep in pediatric primary care: A review of the literature. Sleep Medicine
Reviews, 25, 31-39. doi: 10.1016/j.smrv.2015.01.004

Kelly, Y., Kelly, J., \& Sacker, A. (2013). Time for bed: Associations with cognitive performance in 7-yearold children: A longitudinal population-based study. Epidemiology \& Community Health, 67(11), 926-931. doi: 10.1136/jech-2012-202024

Lélis, A., Cipriano, M., Cardoso, M., Lima, F., \& Araújo, T. (2014). Influência do contexto familiar sobre os transtornos do sono em crianças. Revista Rene, 15(2), 343-353. doi: 10.15253/2175-6783.2014000200020

Monteiro, M. (2014). A importância do sono nas crianças. Lisboa, Portugal: Chiado Editora.

Owens, J., \& Mindell, J. (2011). Pediatric insomnia. Pediatric Clinics of North America, 58(3), 555-569. doi: 10.1016/j.pcl.2011.03.011

Rangel, M., Batista, C., Pitta, M., Anjo, S., \& Leite, A. (2015). Qualidade de sono e prevalência das perturbaçôes do sono em crianças saudáveis em Gaia: Um estudo transversal. Revista Portuguesa de Medicina Geral e Familia, 31(4), 256-264. Retrieved from http://www. rpmgf.pt/ojs/index.php/rpmgf/article/view/11553

Sadeh, A., Tikotzky, L., \& Scher, A. (2010). Parenting and infant sleep. Sleep Medicine Reviews, 14(2), 89-96. doi: 10.1016/j.smrv.2009.05.003

Seixas, M. (2009). Avaliação da qualidade de sono na adolescência: Implicaçôes para a saúde fisica e mental (Master's dissertation). Retrieved from http://bdigital.ufp.pt/ handle/10284/1256

Semedo, E. (2016). 10 mandamentos para crianças: Do nascimento aos 12 anos de idade. Retrieved from http:// cdn.worldsleepday.org/wp-content/uploads/2015/09/ WSD-2016-Resources-10-Commandments-forChildren-PT.pdf

Silva, H. C. (2012). Adaptação e validação do Children Sleep Habits Questionnaire e do Sleep Self Report para crianças portuguesas (Master's dissertation). Retrieved from http:// repositorio.ul.pt/bitstream/10451/8924/1/678220_ Tese.pdf

Talhada, L. C. (2012). Qualidade do sono, saúde e estilos de vida: Estudo com a população activa portuguesa (Master's dissertation). Retrieved from https://ubibliorum. ubi.pt/handle/10400.6/2663

Teng, A., Bartle, A., Sadeh, A., \& Mindell, J. (2012). Infant and toddler sleep in Australia and New Zealand. Journal of Paediatrics and Child Health, 48(3), 268273. doi: 10.1111/j.1440-1754.2011.02251.x 